\title{
Research on the Development Process and Educational Research Status of College Students' Career Development and Employment Guidance Course*
}

\author{
Penggang Zhang \\ College of Economics and Management \\ Hubei University of Automotive Technology \\ Shiyan, China 442002
}

\author{
Qian Zhang \\ College of Economics and Management \\ Hubei University of Automotive Technology \\ Shiyan, China 442002
}

\begin{abstract}
Since the introduction of career guidance and career planning in China, domestic scholars have paid more and more attention to the influence of employment guidance and career planning on college students, and carried out more research about it. Moreover, the state has put forward some specific curriculum settings and requirements. The "College Students' Career Development and Employment Guidance Course" has been carried out in colleges and universities nationwide for more than $\mathbf{1 0}$ years. Due to differences in the quality of students, the construction of curriculum system and the quality of teachers, the quality and level of the course development in different universities are uneven, and there are some common problems.
\end{abstract}

Keywords-development history; career planning; employment guidance; educational research

\section{INTRODUCTION}

As the number of college graduates increases year by year, the employment issue has once again become the focus of social attention. How to improve the employment quality of college graduates has become one of the important tasks of college personnel training. In the face of severe employment situation, universities must strengthen the construction of employment guide courses, career planning courses and other related courses, and actively guide college graduates to achieve high-quality employment.

The "College Students' Career Development and Employment Guidance Course" is an important course in the employment work of colleges and universities. The development status and quality and level of the course will affect the employment concepts and employment choices of college graduates to some extent. It will also affect the

*Fund Project: This article is the phased research result of Hubei provincial humanities and social science project "Research and Practice of Innovation and Entrepreneurship Education in Hubei Local Universities Based on Career Planning” (Project No.: 18Q110), Hubei University of Automotive Technology student work quality project "Research on the Effectiveness and Promotion Strategies of Innovation and Entrepreneurship Education in Local Engineering Colleges and Universities" (Project No. 2018XGYJ08). employment rate and quality of employment for graduates invisibly. This paper takes the development history and research status of college students' career development and employment guidance course as the research content. It aims to review the development process of career guidance and career planning, summarize the problems common in colleges' construction and development of the course, and then propose more reasonable improvement measures and opinions.

\section{RESEARCH ON THE DEVELOPMENT HISTORY AND} EVOLUTION OF THE COURSE OF COLLEGE STUDENTS' CAREER DEVELOPMENT AND EMPLOYMENT GUIDANCE

In the early stage, career planning evolved from career guidance. The earliest career guidance concept was proposed by Parsons, who is known as the "father of career guidance" in the United States. "In 1903, he began to promote career guidance in Boston. In 1908, he established a career bureau in Boston, organized and promoted the career guidance, and career guidance had become more and more perfect. Boston had become the birthplace of career guidance in American." At that time, the unemployment of young people in the society was severe, so the career guidance was highly valued by the government and society, and gradually became specialized, and was considered to be in the same important position with doctors, lawyers, teachers, etc. Subsequently, special courses in vocational guidance had been gradually set up in various universities. At the same time, the national vocational guidance association and local chapters had also been established successively, and the "Career Guidance Magazine" was set up for the publication of career guide information and the results of related research. Career guidance was then on the right track, and the banner of career guidance was also erected in the world.

Affected by the US career guidance, the career guidance in other European countries had also been vigorously developed, mainly to solve social employment problems, for example, "The British career guidance organizations in fact were established according to two kinds of motions of the legislature: The first was the 'Laws for Employment Agencies' passed in 
1909, another was the 'Laws of Choosing Career' adopted in 1910." Although the career guidance in different parts of the UK was different from each other in methods, they were all based on these two laws. The two laws complemented each other, integrated with each other and jointly provided career guidance for the unemployed. Occupation introductions in England, Wales and other places were carried out by the Ministry of Commerce and youth employment agencies were set up. There were more than 130 youth employment agencies at the time. In the local towns, the educational institutions set up the youth employment agencies. They must first declare the setting of the agencies, write reasons and plans, and report them to the Ministry of Education. The Ministry of Education negotiated with the Ministry of Commerce whether it was feasible, and then gave certain funds and carried out corresponding activities. The places where the model worked well were Birmingham, Liverpool and Cambridge.

For the early career guidance of Germany, before the First World War, employment assistance activities were carried out mainly by the two institutions of schools and labor bureaus. In addition to labor bureaus, local authorities set up career guidance offices. The most famous was the career guidance promoted by Dr. Wolfe of the statistical office of Halle City. It was very professional and targeted, and its effect was the best, and there were more than eleven places that followed his career guidance method. On March 18, 1919, the German Ministry of Internal Affairs, Ministry of Industry and Commerce, Ministry of Agriculture and Ministry of Education issued an order together to require cities with the population of over 10,000 to establish career guidance offices to provide professional employment guidance for young people. "For both male and female students, when they were leaving schools, they would all be investigated by the career guidance offices. The offices would check students' family status, employment conditions, etc. in detail. The schools were also responsible for providing various reports and data on students' abilities and physiques for the offices."

After the Second World War, the concentration of social youth and post-war demobilized restorers made occupational guidance gradually become the focus of social attention. Career guidance also experienced two major changes: one was the transition from the static, one-time career guidance to the developmental, multi-finished career choice; the second was the transition from vocational guidance to vocational assistance, which turned the teaching-oriented career guidance mode into the more humane career assistance mode that emphasized the role of the tutee. During the period of the second change, the occupation and career could replace each other, guidance and counseling could replace each other, the function of career counseling gradually reflected in the career guidance, and the career planning was finally formed.

At the beginning of the 20th century, China's career guidance began to sprout under the influence of the United States and other Western countries. In 1916, Mr. Zhou Yichun, the president of Tsinghua University, applied the methods of psychological testing to the career choosing of students for the first time, and implemented the course guidance related to "career planning", which was the pioneering work of Chinese career planning education.
As the first professional career guidance institution in China, the China Vocational Education Association was a mass organization led by the Communist Party of China which was "at the united front, educational and non-governmental". It was mainly composed of people engaged in and caring for vocational education in the education and economic circles. And it was the bridge and bond for the party and the government to unite and connect related persons in the vocational education circle and the private education circle. The China Vocational Education Association was founded in Shanghai on May 6, 1917 by Mr. Huang Yanpei, the famous educator and patriotic democrat in China, together with other 48 famous educators and industry celebrities such as Cai Yuanpei, Liang Qichao, Zhang Jian, Song Hanzhang, etc. At the beginning of the establishment of the association, it took advocating, researching and promoting vocational education, and reforming the traditional education that was separated from productive labor and social life as its mission. It proposed that the purpose of vocational education was to "develop the personality, prepare for the individual's livelihood, prepare for individuals' serving the society, and prepare for the promotion of productivity for the country and the world""Enable the unemployed to have a job, and enable the employed to be enthusiastic about their work", and it made unremitting efforts for this purpose, becoming the forerunner of reform in the history of modern Chinese education. In 1918, the "Career Guide" was published, and in 1919, the Career Guidance Department was established, and the "Career Guidance" was published in the "Education and Occupation" magazine for publicity and promotion. In 1923, the "Career Guidance" was published. In 1924, the "career guidance committees" in primary and secondary schools was promoted and established;

In the same year, Tsinghua School President Zhou Jimei initiated a career choice speech campaign to guide students in career selection, hired celebrities and experts to enter the school to give lectures on career issues, and guide students to fill in the wish work sheets to predict employment trends and provide a basis for the determination of the career guidance discipline. This activity had created a precedent for the employment guidance in China.

In 1927, the China Vocational Education Association established the first "career guidance center" in Shanghai. Since then, a number of career guidance centers had been established in various places, laying a foundation for the development of career guidance in China.

In the $1920 \mathrm{~s}$ and $1930 \mathrm{~s}$, a series of books on career guidance were published. As early as in 1923, when the theoretical research on career guidance in foreign countries had just started, Zou Enrun had translated and edited the book "Career Guidance". Through the definition of the scope of career guidance, the book pointed out the utility, organs and methods of career guidance. This book is the first book in China to systematically discuss career guidance. It is a pioneering work on the theoretical research of career guidance in China. Later, Yu Jianqing and Chen Chongyin's "Educational and Vocational Guidance for Primary and Secondary School Students", Jiang Hengyuan's "How to Run Career Guidance", He Qingru's "Vocational Guidance", Pan Wen'an's "Career Guidance", etc. had been published in 
succession, which has certain theoretical value for both theoretical and practical research of career guidance in China.

Since then, the career guidance theories of Europe countries, America and Japan had been introduced to China in succession. The "Education and Occupation" magazine, sponsored by the China Vocational Education Association, dealt with career guidance issues in almost every issue. While Huang Yanpei, Cai Yuanpei, $\mathrm{Hu}$ Shi and other famous educators and industry celebrities actively participated in the discussion of career guidance and vocational education, the theory of career guidance became an ideological trend, and had an important impact on the development of practice activities and educational theories of the reform in the school system and the educative reform in the 1920s. However, due to the turmoil of the society at the time, the theory of career guidance was not really universally applied to practice.

Beginning in the mid-1930s, with the intensification of the national crisis and the outbreak of the civil war after the victory of the Anti-Japanese War, the theory of career guidance gradually withdrew from the historical arena.

After the founding of the People's Republic of China, vocational planning education and employment guidance work did not receive sufficient attention due to the implementation of the planned economy and the unified distribution in employment. Since the reform and opening up, higher education has undergone reforms. In the mid-to-late 1990s, the employment model of "two-way choice and independent employment" between graduates and employers was finally implemented nationwide. At this time, there was basically no career planning education in colleges and universities. There was only simple employment guidance education. And the education was only for the graduates. The form of guidance was single and the content was simple, which was far from the requirement of professional development.

The second reform happened in the 1990s. In 1995, the General Office of the former State Education Commission issued the "Notice on Opening Employment Guidance Selective Courses in Colleges and Universities", requiring universities to set up employment guidance courses to help college students establish good employment concepts and achieve better employment. In 1997, the China Higher Education Student Career Center formulated the "Syllabus for Employment Guidance for College Students", which provided guidance for the development of employment guidance for students in colleges and universities. In the same year, the State Education Commission issued the "Interim Provisions on the Employment of Graduates of Regular Colleges and Universities" (Teaching [1997] No. 6), which clearly defined the employment guidance work of colleges and universities, and various universities had established corresponding institutions in succession.

In 2007, the Ministry of Education promulgated the "Teaching Requirements for College Students' Career Development and Employment Guidance Course" (Higher Education Department [2007] No. 7), which stipulates: "Since 2008, all regular colleges and universities are encouraged to offer career development and employment guidance courses, take them as the general courses and include them in the teaching plan. These courses should run through the entire training process from the entrance to the graduation of the students". Compared with the textbooks and syllabus of the employment guidance courses promulgated in 1997, the content of career planning counseling has been added, and the transition from "employment guidance" to "career planning education" has been preliminarily realized. The teaching concept is more advanced and the guidance work is more comprehensive and meticulous, the safeguard measures are more solid and powerful.

Under the dual role of national policy guidance and graduate employment issues, the construction of the "College Students' Career Development and Employment Guidance Course" in colleges and universities is becoming more and more important. The curriculum construction and teaching quality and level will to a certain extent affect the quality of schools' personnel training.

\section{RESEARCH ON THE TEACHING OBJECTIVES AND TEACHING STATUS OF COLlEGE STUDENTS' CAREER \\ DEVELOPMENT AND EMPLOYMENT GUIDANCE COURSE}

According to the "Notice of the General Office of the State Council on Doing a Good Job in the Employment of Graduates of Ordinary Colleges and Universities in 2007", the Ministry of Education formulated the "Teaching Requirements for College Students' Career Development and Employment Guidance Courses", requiring universities to formulate scientific, systematic and distinctive syllabus basing on their actual conditions, organize the construction of their own college students' career development and employment guidance courses and the implementation of corresponding teaching activities, and actively promote the employment of college graduates.

Through the teaching of this course, college students should achieve the following goals in terms of attitude, knowledge and skills.

Attitude: Through the teaching of this course, college students should establish the self-awareness of career development, establish a positive and correct outlook on life, values and employment concepts, combine personal development with national needs and social development, and establish the concept and consciousness of occupation, willing to take active efforts for personal career development and social development.

Knowledge: Through the teaching of this course, college students should have a basic understanding of the characteristics of career development stages; more clearly understand their own characteristics, characteristics of occupations and social environment; understand the employment situation and policies and regulations; master the basic labor market information, related occupational classification knowledge and basic knowledge of entrepreneurship.

Skills: Through the teaching of this course, college students should master self-exploration skills, information search and management skills, career decision-making skills, 
job search skills, etc., and should also improve various general skills, such as communication skills, problem-solving skills, self-management skills and interpersonal skills.

In the research on the teaching status quo of "College Students' Career Development and Employment Guidance Course", it is found that there are still some gaps between students' achieving status quo of the three goals and the requirements, which are mainly reflected in the following aspects:

First, the attitude: the teaching goal is to help college students establish a good social outlook, outlook on life and values, and then enable them to have a good view of employment when they graduate. In reality, most college students are post 90s. In the era of the current developed information network, they have more channels to obtain information and understand information, and can quickly get the information. So they are easy to be influenced by the biased, unhealthy and even negative concepts of employment on the Internet. When they graduate, they will probably be negative in obtaining employment, and will be the students not getting employed, even the students going home to "live on parents".

At the same time, the study also found that in the establishment of college courses, career planning and employment guidance courses are mostly elective courses, the degree of attention for the courses is not enough, the students' learning effect is generally poor, and students generally lack understanding of the course.

The second is the knowledge: the level of understanding of professional knowledge can affect the judgment of future professional career development to a certain extent. The goal of the career planning and employment guidance course at the knowledge level is to enable students to fully know themselves and understand professional knowledge, and have a certain understanding of occupations in combination with the current social development, and make a reasonable career planning. However, in reality, graduates still have a bias in understanding their professional knowledge. They cannot fully understand the nature of the profession and their future development. They lack understanding of the concept of occupations, which leads to their blind follow-up when choosing their careers. Finally, they will find that they are not suitable for the careers they have chosen and will resign or change jobs, missing good job opportunities.

The post-90s college students lack understanding of themselves. They rely too much on multimedia social platforms such as mobile phones, and gradually lose the ability to think independently. They can not make rational judgments on social phenomena and often "echo the views of others", not having their own opinions and scientific "self-concepts".

The third is the skill: the ability to search for information, integrate information, and understand information is a skill that must be mastered in today's Internet age, and making students master this ability is one of the main teaching tasks of the Career Planning and Employment Guidance Course. However, through research, it is found that the ability of college students to master and search information still needs to be improved; in terms of communication skills, because college students rely too much on social networks, their ability to communicate with people in reality is slightly poor; And their ability to solve problems and self-management capabilities also need to be strengthened.

\section{CONCLUSION}

College student career planning and employment guidance courses have been opened in colleges and universities for more than 10 years. According to the current research literature on the teaching effects, there is still a gap between college students' actual abilities and the three teaching goals, In terms of the setting goals and contents of the course, the career planning and employment guidance course can help college students get a clear understanding of themselves and determine their career goals. The most important thing is that the course embodies the close combination of learning and application, and improves the quality and level of talent training in colleges and universities. However, it can be seen from the development history of career planning and employment guidance courses and the research in recent years that, local colleges and universities are at a low level in terms of curriculum setting and students' learning effects. Local colleges and universities need to improve the emphasis on the course, improve the teaching level and teaching methods; pay attention to the quality of teaching and the experience of students, increase the practice of the curriculum, and jointly improve the quality and level of the course.

\section{REFERENCES}

[1] Notice of the General Office of the Ministry of Education on Printing and Distributing the Teaching Requirements for College Students' Career Development and Employment Guidance Courses. [EB/OL]http://www.moe.gov.cn/publicfiles/business/htmlfiles/moe/moe _745/200802/11260.html [2013-12-13].

[2] Zhao Shengli et al. Research on the differences in employment guidance for college studentsbetween Chinese and American schools[J], Continue Education Research, 2007, 08: pp.66-68.

[3] Xiang Yingfang. Research on career planning of college students: Take Shanxi undergraduate college as an example [D], Shandong: Shandong University, 2010.

[4] Zhang Penggang. Research on the Learning Effect of College Students Career Planning Course[J], Journal of Dezhou University, 2014.07:pp.46-49.

[5] Zhang Penggang et al. Research on the status quo of self-cognition of post-90s college students[J], Journal of Higher Education, 2015.01:pp.76-78. 